\title{
Assessment of Suspected Breast Lesions in Early Stage Triple Negative Breast Cancer During Follow- up After Breast Conserving Surgery Using Multiparmetric MRI
}

Research article

Keywords:

Posted Date: December 16th, 2020

DOI: https://doi.org/10.21203/rs.3.rs-101187/v2

License: (1) This work is licensed under a Creative Commons Attribution 4.0 International License.

Read Full License

Version of Record: A version of this preprint was published at International Journal of Breast Cancer on February 18th, 2022. See the published version at https://doi.org/10.1155/2022/4299920. 


\section{Abstract}

The authors have requested that this preprint be withdrawn due to author disagreement.

\section{Full Text}

The authors have withdrawn this preprint from Research Square. 